"Vol 3, No 1 (2019): July - Desember"

ISSN : 2598-831X (Print)
ISSN :2598-8301 (Online)

\title{
ANALISIS PROFITABILITAS UNTUK MENGUKUR KINERJA KEUANGAN MANAJEMEN HOTEL SYARIAH "AL BADAR” DI KOTA MAKASSAR
}

\section{Profitability Analysis To Measure Financial Performance of "Al Badar" Sharia Hotel Management In Makassar}

\author{
Muliana \\ Manajemen Universitas Fajar \\ Email : mulianafachrul@gmail.com \\ Nurbayani \\ Universitas Fajar \\ Email : nurrahman260114@gmail.com
}

\begin{abstract}
ABSTRAK
Tidak bisa dipungkiri bahwa perkembangan label syariah pada dunia bisnis di Indonesia saat ini telah menjadi trend tersendiri. Hotel syariah adalah hotel yang penyediaan, pengadaan, produk dan fasilitas operasionalnya berdasarkan prinsip syariah islam. Penelitian ini bertujuan untuk mengetahui dan menganalisis kinerja keuangan Hotel Syariah "Al Badar" selama tahun 2014-2018 berdasarkan Net Profit Margin (NPM) dan Return On Asset (ROA). Penelitian ini dilakukan pada Hotel Syariah "Al Badar" di Kota Makassar. Metode analisis yang digunakan adalah metode analisa deskriptif kuantitatif. Hasil penelitian menunjukan bahwa Kinerja keuangan Hotel Syariah "Al Badar" selama kurun waktu 5 (lima) tahun (2014-2018) berdasarkan Net Profit Margin (NPM) dinilai kurang. Hal ini berdasarkan hasil perhitungan rata-rata Net Profit Margin (NPM) sebesar 10,4\%
\end{abstract}


"Vol 3, No 1 (2019): July - Desember"

yang masih dianggap kurang dari $20 \%$ berdasarkan standar industri. Return On Asset (ROA) menunjukkan hasil yang sangat kurang. Hal ini berdasarkan nilai perhitungan rata-rata sebesar $\mathbf{0 , 5 0 \%}$. Hal ini berarti profitabilitas Hotel Syariah "Al Badar" masih sangat jauh dibawah standar Industri Return On Asset (ROA) yaitu sebesar $30 \%$.

Kata-kata Kunci : Hotel Syariah, Net Profit Margin (NPM), Return On Asset (ROA)

\begin{abstract}
It cannot be denied that development of sharia business label in Indonesia has become a trend. Sharia hotel is a hotel that provide, procure, using product, facilities and its operational are based on Islamic sharia rules. This study aims to determine and analyze the financial performance of "Al Badar" Syariah Hotels during 2014-2018 based on Net Profit Margin (NPM) and Return On Asset (ROA). This research was conducted at the "Al Badar" Syariah Hotel in Makassar City. The analytical method used is quantitative descriptive analysis method. The results showed that the financial performance of the "Al Badar" Syariah Hotel for a period of 5 (five) years (2014-2018) based on Net Profit Margin (NPM) was judged to be lacking. This is based on the calculation of the average Net Profit Margin (NPM) of $10.4 \%$ less than $20 \%$ based on industrial standard. Return On Assets (ROA) shows very poor results based on an average calculation value of $0.50 \%$. It means that the profitability of the Sharia Hotel "Al Badar" is still far below the Industrial standard of Return On Asset (ROA) of $30 \%$.
\end{abstract}

Keywords: Sharia Hotel, Net Profit Margin (NPM), Return On Assets (ROA)

\title{
PENDAHULUAN
}

Perekembangan bisnis di Indonesia akhir-akhir ini sangat beragam. Bukan hanya bisnis yang bergerak dibidang barang, akan tetapi bisnis yang bergerak di bidang jasa juga sangat bergam. Keberagaman bisnis yang ada tidak lepas dari tingginya kebutuhan konsumen akan produk (barang dan jasa) tersebut. Indonesia dengan destinasi wisata yang sangat beragam di berbagai propinsi menjadikan bisnis bidang jasa juga sangat diminati. Hotel merupakan salah satu kebutuhan bagi wisatawan yang berkunjung ke lokasi destinasi wisata.

Sulawesi Selatan merupakan salah satu propinsi tujuan destinasi wisata yang beragam dan sedang bekembang. Berdasarkan data yang ada, sepanjang tahun 2017 kunjungan wisatawan mancanegara ke Sulawesi Selatan mencapai 
17.719 atau meningkat sebesar 5,08 persen dibandingkan jumlah kunjungan wisatawan tahun 2016 yang berjumlah 16.862 kunjungan. Sementara itu tingkat penghunian kamar hotel klasifikasi bintang pada Desember 2017 sebesar 53,90 persen dari bulan November 2017 (www.makassar.tribunnews.com). Data terkini tercatat jumlah kunjungan ke Kota Makassar pada tahun 2017 lalu sebanyak 2.334.619 orang, data yang tercatat sampai bulan juni 2018 jumlah kunjungan mencapai 2.550 .760 orang atau meningkat sebesar 9,73 persen dibanding tahun sebelumnya (www.rakyatsulsel.com). Berdasarkan data tersebut, keberadaan hotel di kota Makassar sangat berperan dalam memenuhi permintaan wisatawan.

Tidak bisa dipungkiri bahwa perkembangan label syariah pada dunia bisnis di Indonesia saat ini telah menjadi tren tersendiri. Hotel syariah atau hotel berbasis syariah adalah hotel yang dalam penyediaan, pengadaan dan penggunaan produk dan fasilitas serta dalam operasional usaha tidak melanggar aturan syariah, berusaha dengan sistemnya untuk meminimalisir dan menghilangkan kemungkinan terjadinya penyalahgunaan fasilitas oleh pengguna jasa. Beberapa ciri yang membedakan hotel syariah dari hotel konvensional antara lain Peraturan hotel syariah, Pengelolaan dana, Fasilitas, Pelayanan, Makanan dan Minuman.

Hotel Al-Badar merupakan Hotel syariah pertama yang ada di kota Makassar. Hotel ini didirikan sejak tahun 2012. Berdirinya Hotel Al-Badar berdasarkan kondisi beberapa hotel di kota Jakarta yang berbasis konsep syariah. Pemilik hotel melihat adanya pangsa pasar yang cukup besar, sehingga pemilik membuka bisnis di kota Makassar dengan konsep yang sama, yaitu hotel berbasis syariah. Oleh karena itu, didirikanlah Hotel Al-Badar dengan konsep syariah yang sesuai ajaran islam dan diharapkan bebas dari hal-hal negatif.

Penilaian kinerja keuangan dapat menginformasikan kondisi keuangan suatu perusahaan dalam keadaan baik maupun tidak. Selain itu penilaian kinerja keuangan sangat penting bagi manajer untuk mengambil kebijakan dan strategi kedepannya. Pada dasarnya penilaian kinerja keuangan setiap perusahaan berbeda-beda, bisa dengan membandingkan dari tahun-tahun sebelumnya atau membandingkan dengan standar industri yang sejenis. Era perekonomian yang tidak pasti, perusahaan berbasis laba dituntut lebih berinovasi untuk mencapai target yang ditentukan. 
"Vol 3, No 1 (2019): July - Desember"

\section{KAJIAN PUSTAKA}

\section{Pengertian Laporan Keuangan}

Laporan keuangan menurut Standard Akuntansi Keuangan (SAK) 2015 adalah merupakan bagian dari proses pelaporan keuangan. Laporan keuangan yang lengkap biasanya meliputi neraca, laporan laba rugi, laporan perubahan posisi keuangan (yang dapat disajikan dalam berbagai cara misalnya sebagai laporan arus kas, atau laporan arus dana), catatan dan laporan lain serta materi penjelasan yang merupakan bagian integral dari laporan keuangan. Secara umum, laporan keuangan adalah catatan informasi keuangan suatu perusahaan pada suatu periode akuntansi yang dapat digunakan untuk menggambarkan kinerja perusahaan tersebut (Sujarweni, 2017).

\section{Teknik Analisis Laporan Keuangan}

Ada 3 macam teknik analisis laporan keuangan :

1. Analisis rasio keuangan

2. Perbandingan laporan keuangan

3. Analisis trend

\section{Analisis Rasio Keuangan}

Analisis rasio keuangan merupakan aktivitas untuk menganalisis laporan keuangan dengan cara membandingkan satu akun dengan akun lainnya yang ada dalam laporan keuangan, perbandingan tersebut bisa antar akun dalam laporan keuangan neraca maupun laba rugi.

Dalam praktiknya terdapat beberapa macam jenis rasio keuangan yang dapat digunakan dalam mengukur kinerja suatu perusahaan. Masing-masing jenis rasio yang digunakan akan memberikan arti tertentu tentang posisi yang diinginkan,penelitian ini menggunakan rasio profitabilitas.

\section{Rasio Profitabilitas \\ Rasio profitabilitas merupakan rasio untuk menilai kemampuan perusahaan dalam mencari keuntungan. Rasio ini juga memberikan ukuran}


tingkat efektivitas manajemen suatu perusahaan. Hal ini ditunjukkan oleh laba yang dihasilkan dari penjualan dan pendapatan investasi. Intinya bahwa penggunaan rasio ini menunjukkan efisiensi perusahaan. Rasio ini digunakan untuk mengukur tingkat imbalan atau perolehan (keuntungan) dibanding penjualan atau aktiva, mengukur seberapa besar kemampuan perusahaan memperoleh laba dalam hubungan dengan penjualan, aktiva dan modal sendiri.

\section{Kinerja Keuangan Perusahaan}

Dalam sistem perencanaan dan pengendalian manajemen, ada empat pusat pertanggungjawaban yang perlu mendapatkan perhatian, yaitu: pusat pertanggungjawaban terhadap pendapatan, pusat pertanggungjawaban terhadap biaya, pusat pertanggungjawaban terhadap laba, dan pusat pertanggungjawaban terhadap investasi. Dalam kaitannya dengan pusat pertanggungjawaban terhadap laba, maka penilaian kinerja keuangan dapat diukur dengan Rasio Profitabilitas.

Rasio Profitabilitas meliputi banyak rasio, dimana yang diganakan dalam penelitian ini adalah Rasio Net Profit Margin (NPM) dan Return on Total Assets (ROA). Net Profit Margin (NPM) adalah perbandingan antara laba dengan penjualan.

a. Net Profit Margin (NPM)

Net Profit Margin (NPM) menggambarkan tentang seberapa besar laba yang diperoleh perusahaan atas penjualan (income) selama periode tertentu. Semakin tinggi persentase NPM menunjukkan bahwa sebagian besar penjualan dapat dialokasikan pada laba dan hal ini menunjukkan bahwa perusahaan telah mampu menekan biaya secara efektif. Sebaliknya, jika persentase NPM kecil menunjukkan bahwa perusahaan tidak mampu menekan biaya yang berdampak pada tingginya beban perusahaan yang berakibat pada rendahnya kontribusi penjualan atas laba. NPM juga mengukur seluruh efisiensi, baik produksi, administrasi, pemasaran, pendanaan, penentuan harga maupun manajemen pajak (Ismani, 2011). NPM dapat dihitung dengan cara sebagai berikut:

$$
\text { NPM }=\frac{\text { Laba Bersih }}{\text { Penjualan }} \times 100 \%
$$


"Vol 3, No 1 (2019): July - Desember"

b. Return on Total Assets ( ROA)

Return on Total Assets (ROA) mengukur kemampuan perusahaan dalam memanfatkan aktivanya untuk memperoleh laba. Rasio ini mengukur tingkat kembalian investasi yang telah dilakukan oleh perusahaan dengan menggunakan seluruh dana (aktiva) yang dimiliki. Rasio ini dapat diperbandingkan dengan tingkat bunga bank yang berlaku (Ismani,2011). ROA dapat dihitung dengan menggunakan formula sebagai berikut:

$$
\text { ROA }=\frac{\text { Laba Bersih }}{\text { Total Aktiva }} \times 100 \%
$$

\section{METODOLOGI PENELITIAN}

Penelitian ini menggunakan pendekatan deskriptif kuantitatif yaitu menggambarkan bagaimana penilaian kinerja dengan menggunakan angka rasio keuangan, yaitu rasio profitabilitas. Penelitian ini menganalisis Kinerja Keuangan berdasarkan rasio profitabilitas yaitu Net Profit Margin (NPM) dan Return On Asset (ROA).

Objek penelitian dalam penelitian ini adalah laporan keuangan dalam bentuk neraca dan laporan laba rugi Hotel Syariah "Al Badar" Makassar, periode tahun 2014-2018.

Metode pengumpulan data yang dilakukan ada 2 (dua); pertama, Studi Dokumentasi, pengumpulan data yang tersedia pada perusahaan berupa laporan keuangan yang berhubungan dengan objek penelitian yang nantinya data tersebut digunakan sebagai acuan dan bahan pertimbangan terhadap apa yang ada dilapangan. Kedua, Studi kepustakaan yaitu mengumpulkan informasi yang diperoleh dengan membaca literature dan catatan lainnya yang berhubungan dengan konsep teori rasio profitabilitas untuk menunjang penelitian yang dilakukan dengan mengutip beberapa teori yang dikemukakan beberapa ahli yang berkaitan dengan permasalahan yang dibahas.

Analisis data merupakan proses penyederhanaan data ke dalam bentuk yang lebih mudah dibaca dan diinterpretasikan. Metode analisis data yang digunakan dalam penelitian ini adalah metode analisa deskriptif, yaitu 
menggambarkan bagaimana penilaian kinerja dengan menggunakan angka rasio keuangan, yaitu rasio profitabilitas. Langkah-langkah yang dilakukan :

1. Mengumpulkan data-data yang dibutuhkan seperti laporan keuangan Hotel Syariah "Al Badar"

2. Menggunakan data yang ada dengan rumus rasio profitabilitas yang terdiri dari Net Profit Margin dan Return On Asset (ROA)

3. Menginterpretasikan data yang telah dihitung menggunakan rasio yang merupakan inti dari proses analisis sebagai perpaduan antara hasil pembanding/pengukur dengan kaidah teoritis yang berlaku.

Menyimpulkan masalah yang terjadi dari hasil perhitungan rasio untuk mengetahui penyebab terjadinya masalah yang terjadi pada masalah tersebut.

\section{HASIL}

\section{a. Standar Rasio Industri Profitabilitas}

Untuk mengukur rasio keuangan, kita membutuhkan standar untuk perbandingan. Salah satu pendekatan adalah dengan membandingkan rasiorasio perusahaan dengan standar Industri atau lini usaha dimana perusahaan secara dominan beroperasi. Berikut adalah tabel standar rasio Industri rata-rata :

Tabel 1

Standar Rasio Industri Profitabilitas

\begin{tabular}{cccccc}
\hline \multicolumn{2}{c}{ Net Profit Margin } & \multicolumn{2}{c}{ Return On Asset } & \multicolumn{2}{c}{ Return On Equity } \\
\hline$\%$ & Kriteria & $\%$ & Kriteria & $\%$ & Kriteria \\
\hline$>\mathbf{2 0}$ & Sangat Baik & $>30$ & Sangat Baik & $>40$ & Sangat Baik \\
\hline $\mathbf{2 0}$ & Baik & 30 & Baik & 40 & Baik \\
\hline $\mathbf{1 5}$ & Cukup & 25 & Cukup & 30 & Cukup \\
\hline $\mathbf{1 0}$ & Kurang & 20 & Kurang & 25 & Kurang \\
\hline$<10$ & Sangat & & Sangat & & Sangat \\
& Kurang & $<20$ & Kurang & $<25$ & Kurang \\
\hline
\end{tabular}

Sumber : Kasmir $(2013: 134)$ 
"Vol 3, No 1 (2019): July - Desember"

a. Hasil Perhitungan Kinerja Keuangan Berdasarkan Net Profit Margin (NPM)

Tabel 2

Hasil Perhitungan Net Profit Margin

Hotel Syariah “Al Badar” selama tahun 2014-2018

\begin{tabular}{cc}
\hline Tahun & Net Profit Margin (\%) \\
\hline $\mathbf{2 0 1 4}$ & 10,01 \\
\hline $\mathbf{2 0 1 5}$ & 10,64 \\
$\mathbf{2 0 1 6}$ & 12,72 \\
\hline $\mathbf{2 0 1 7}$ & 17,99 \\
\hline $\mathbf{2 0 1 8}$ & 0,65 \\
\hline Rata-rata & $\mathbf{1 0 . 4}$ \\
\hline
\end{tabular}

Sumber : Data Diolah

$$
\begin{aligned}
\text { Tahun } 2014 & =\frac{83,250,650}{831,795,300} \times 100 \% \\
= & 10,01 \% \\
\text { Tahun } 2015 & =\frac{79,428,420}{746,512,000} \times 100 \% \\
= & 10,64 \% \\
\text { Tahun } 2016 & =\frac{96,812,35}{761,099,000} \times 100 \% \\
= & 12,72 \% \\
\text { Tahun } 2017 & =\frac{141,397,252}{786,143,000} \times 100 \% \\
= & 17,99 \% \\
\text { Tahun } 2018 & =\frac{4,311,000}{663,769,500} \times 100 \% \\
= & 0,65 \%
\end{aligned}
$$

b. Hasil Perhitungan Kinerja Keuangan Berdasarkan Return On Asset (ROA)

\section{Tabel 3}

Hasil Perhitungan Return On Asset Hotel Syariah “ Al Badar” tahun 2014-2018

Tahun Return On Asset


"Vol 3, No 1 (2019): July - Desember"

\begin{tabular}{cc}
\hline & $\mathbf{( \% )}$ \\
\hline $\mathbf{2 0 1 4}$ & 0.62 \\
\hline $\mathbf{2 0 1 5}$ & 0.53 \\
\hline $\mathbf{2 0 1 6}$ & 0.57 \\
\hline $\mathbf{2 0 1 7}$ & 0.79 \\
\hline $\mathbf{2 0 1 8}$ & 0.02 \\
\hline Rata-rata & $\mathbf{0 . 5 0}$ \\
\hline Sumber : Data Diolah &
\end{tabular}

$$
\begin{aligned}
\text { Tahun } 2014 & =\frac{83,250,650}{13.500 .000 .000} \times 100 \% \\
& =0.62 \% \\
\text { Tahun } 2015 & =\frac{79,428,420}{15.000 .000 .000} \times 100 \% \\
& =0.53 \% \\
\text { Tahun } 2016 & =\frac{96,812,350}{17.000 .000 .000} \times 100 \% \\
& =0.57 \% \\
\text { Tahun } 2017 & =\frac{141,397,252}{18.000 .000 .000} \times 100 \% \\
& =0.79 \% \\
\text { Tahun } 2018 & =\frac{4,311,000}{20.000 .000 .000} \times 100 \% \\
& =0.02 \%
\end{aligned}
$$

\section{PEMBAHASAN}

Net Profit Margin atau margin laba bersih adalah keuntungan penjualan setelah menghitung biaya/beban bunga dan pajak penghasilan. Semakin tinggi Net Profit Margin (NPM), semakin baik operasional suatu perusahaan. Berdasarkan hasil perhitungan Net Profit Margin (NPM), maka dijelaskan bahwa pada tahun 2014 nilai NPM sebesar 10,01\%. Hal ini berarti setiap Rp 1,- penjualan akan menghasilkan keuntungan bersih sebesar Rp 0,1001,-. Pada tahun 2015, Net Profit Margin (NPM) sebesar 10,64\%. Hal ini menunjukkan ada kenaikan sebesar $0,63 \%$. 
Pada tahun 2016, Net Profit Margin (NPM) sebesar 12,72\%, ada kenaikan sebesar 2,08\% dari tahun 2015. Hal dikarenakan ada kenaikan laba bersih dari tahun 2015 ke 2016 sebesar Rp 17.384.930,- (Rp 79,428,420,- menjadi Rp $96,812,350,-$ ). Begitu juga pada tahun 2017, ada kenaikan profit margin sebesar $5,27 \%$ dari NPM 12,72 \% menjadi 17,99\%. Hal ini dikarenakan ada kenaikan laba bersih sebesar $\operatorname{Rp} 44.584 .902,-(\operatorname{Rp} 96,812,350,-$ menjadi $\operatorname{Rp} 141,397,252,-$ ). Tahun 2018 Net Profit Margin (NPM) sebesar 0,65\%. Hal ini menunjukkan penurunan yang sangat drastis sebesar $17,34 \%$, penurunan sebesar ini dikarenakan adanya penurunan laba bersih dari tahun 2017 ke tahun 2018 sebesar Rp 137.086.252,- (Rp 141,397,252,- menjadi Rp 4,311,000,-).

Return On Asset (ROA) merupakan pengukuran kemampuan perusahaan secara keseluruhan di dalam menghasilkan keuntungan dengan jumlah aktiva yang tersedia di dalam perusahaan. Semakin tinggi rasio Return On Asset $(R O A)$, semakin baik keadaan suatu perusahaan. Berdasarkan perhitungan dengan menggunakan rumus rasio return on asset (ROA), pada tahun 2014, nilai return on asset sebesar $0,62 \%$. Artinya setiap kenaikan $\mathrm{Rp} \mathrm{1,-} \mathrm{modal} \mathrm{yang}$ diinvestasikan dalam keseluruhan aktiva menghasilkan keuntungan sebesar $R p$ 0,0062 .

Pada tahun 2015, nilai ROA sebesar 0,53\%. Tahun 2016 nilai ROA sebesar $0.57 \%$. hal ini menunjukkan adanya kenaikan sebesar 0,04\% dari tahun 2015 . Dari data yang ada hal ini menunjukkan adanya kenaikan nilai laba bersih dan aktiva perusahaan. Tahun 2017 nilai ROA sebesar 0,79\%. Hal ini menunjukkan adanya kenaikan dari tahun 2016 sebesar 0,22\% dikarenakan adanya kenaikan laba bersih dan nilai aktiva. Tahun 2018, nilai ROA sebesar $0,02 \%$. Hal ini menunjukkan penurunan yang sangat drastis dari tahun sebelumnya sebesar $0,77 \%$. Penurunan nilai ROA ini dikarenakan penurunan nilai laba bersih sementara nilai aktiva meningkat. Dengan demikian secara umum, nilai Return On Asset (ROA) Hotel syariah "Al Badar" tidak menunjukkan adanya kenaikan yang berarti. Akan tetapi, justru nilai ROA yang turun drastis pada akhir tahun 2018 sangat signifikan. 


\section{SIMPULAN}

Kinerja keuangan Hotel Syariah "Al Badar" selama kurun waktu 5 (lima) tahun (2014-2018) berdasarkan Net Profit Margin (NPM) dinilai kurang. Hal ini berdasarkan hasil perhitungan rata-rata Net Profit Margin (NPM) sebesar 10,4\%, masih dinilai kurang berdasarkan standar industri Net Profit Margin yaitu sebesar $20 \%$. Kinerja keuangan Hotel Syariah "Al Badar" berdasarkan analisis Return On Asset (ROA) selama kurun waktu 5 (lima) tahun, yaitu dari tahun 2014-2018 menunjukkan hasil yang sangat kurang. Hal ini berdasarkan nilai perhitungan rata-rata sebesar $0,50 \%$. Hal ini berarti profitabilitas Hotel Syariah "Al Badar" masih sangat jauh dibawah standar Industri Return On Asset (ROA) yaitu sebesar $30 \%$. Berdasarkan informasi yang ada dan hasil perhitungan secara ilmiah, perusahaan diharapkan lebih meningkatkan volume pendapatan jasa melalui promosi untuk penggunaan hotel syariah "Al Badar" baik dengan mengupdate sosial media (sosmed) atau dengan bekerja sama dengan pemerintah dan pihak-pihak terkait, misalnya agen travel atau lembaga lain yang dianggap kegiatan-kegiatannya lebih banyak menggunakan jasa Hotel. Selain itu, evaluasi laporan keuangan setiap bulan dapat memberi gambaran bagaimana kondisi financial perusahaan. Hal ini dapat menjadikan perusahaan lebih peka dalam merumuskan strategi peningkatan penjualan kamar hotel. Pentingnya peran marketing dalam memasarkan hotel syariah "Al Badar" sangat dibutuhkan. Hal ini karena hotel syariah masih harus diterus dikenalkan pada masyarakat, apa kelebihan service yang diberikan dibandingkan dengan hotel yang masih konvensional. Sebaiknya pemerintah Propinsi Sulawesi Selatan umumnya dan pemerintah kota Makassar khususnya meningkatkan target Dinas terkait khususnya dinas pariwisata untuk menambah daya tarik wisatawan dengan meningkatkan daya pikat mereka akan wisata di Kota Makassar khususnya situs sejarah, wisata alam dan banyak lagi kegiatan-kegiatan lain yang akan mengenalkan Makassar dimata dunia. Selain itu, kerjasama antara dinas terkait dengan pihak manajemen hotel, juga diharapkan akan memberi dampak positif bagi perkembangan usaha hotel syariah di Makassar. 
"Vol 3, No 1 (2019): July - Desember"

\section{REFERENSI}

Handayani, Dessie. (2013), Analisis Kinerja Keuangan Berdasarkan Rasio Profitabilitas Pada PT Bhimex Di Samarinda. Jurnal Ekonomi UNMUL Vol. 1 hal. 1

Husnan, Suad., Enny Pudjiastuti. (2015), Dasar-Dasar Manajemen Keuangan. Edisi Ketujuh. UPP STIM YKPN. Yogyakarta.

Ismani.(2011),Analisis Profitabilitas Untuk Mengukur Kinerja Keuangan Manajemen Hotel (Studi Kasus pada UNY-Hotel Yogyakarta). Jurnal Pendidikan Akuntansi Indonesia, Vol. IX. No. 2 HIm. 72 - 78

Jumingan.(2008),Analisis Laporan Keuangan,Bumi Aksara.Jakarta.

Kasmir. (2013), Pengantar Manajemen Keuangan. Edisi Ketiga.

Kencana.Jakarta.

Nasution, Mutia Raisa.(2018),Analisis Rasio Profitabilitas sebagai Alat Untuk Mengukur Kinerja Keuangan Pada PT JAyawi Solusi Abadi Medan. Skripsi. UIN Sumatera Utara.

Pulloh,Joy,dkk.(2016),Analisis Rasio Keuangan Untuk Menilai Kinerja Keuangan Perusahaan (Studi Kasus Pada PT. HM Sampoerna Tbk Yang Terdaftar Di Bursa Efek Indonesia). Jurnal Administrasi Bisnis (Jab)|Vol. 33 No. 1

Prasetyo, Dwi Agung,Ni Putu Ayu Darmayan.(2015),Pengaruh Risiko Kredit, Likuiditas, Kecukupan Modal, Dan Efisiensi Operasional Terhadap Profitabilitas Pada PT BPD Bali. E-Jurnal Manajemen Unud, Vol. 4, No. 9, 2015: 2590- 2617, ISSN : 2302-8912

Prasetyo, Heri. (2014), Manajemen Hotel Syariah.Jurnal Kompetensi 12 (2), 82106

Sabri, Fahruddin Ali. (2010),Perkembangan Hotel Syariah Di Indonesia;Mengonsep Pariwisata Islami. Jurnal Karsa, Vol. Xviii No. 2

Setyo, Budi Nugroho.(2012),Analisis Pengaruh Efisiensi Modal Kerja, Likuiditas Dan Solvabilitas Terhadap Profitabilitas (Studi Kasus Pada PT. Telekomunikasi Indonesia, Tbk). Jurnal

Sujarweni, Wiratna V. (2017), Manajemen Keuangan, Teori, Aplikasi dan Hasil Penelitian. Pustaka Baru Press. Yogyakarta.

Sugiyono. (2014), Metode Penelitian Kombinasi (Mixed Methods). Alfabeta. Bandung.

Widagdyo, Kurniawan Gilang .(2015),Analisis Pasar Pariwisata Halal Indonesia. The Journal Of Tauhidinomics Vol. 1 No. 1 . Hal 73-80

Yulianto, Atun. (2012),Analisis Faktor-Faktor Pertumbuhan Keuangan Hotel Menggunakan Metode Analisis Statis Dan Dinamis (Studi Kasus : PT Hotel Mandarine Regency, Tbk). Jurnal Khasanah IImu, Vol. III No.1

Yulianto, Atun. (2014), Mengukur Kesehatan Keuangan Jasa Perhotelan Dengan Model Altman, Springate Dan Zmijewski. Jurnal Khasanah IImu Vol. V No.

Yusuf, A.Muri. (2014), Metode Penelitian Kuantitatif, Kualitatif \& Penelitian Gabungan. Kencana. Jakarta.

Permenpan 2015.

www.makassar.tribunnews.com 